\title{
SIREX WOODWASP: \\ A Model for Evolving Management Paradigms of Invasive Forest Pests
}

"Corresponding author

\author{
Bernard Slippers, ${ }^{*}$ Brett P. Hurley, and Michael J. Wingfield \\ Department of Genetics and Department of Zoology and Entomology, Forestry \\ and Agricultural Biotechnology Institute, University of Pretoria, Pretoria, 0002, \\ South Africa; email: bernard.slippers@fabi.up.ac.za, \\ brett.hurley@fabi.up.ac.za, mike.wingfield@fabi.up.ac.za
}

\begin{abstract}
The Sirex woodwasp, Sirex noctilio, and its fungal mutualist, Amylostereum areolatum, together constitute one of the most damaging invasive pests of pine. Despite a century of research and well-established management programs, control remains unpredictable and spread continues to new areas. Variable success in managing this pest has been influenced by complex invasion patterns, the multilayered nature of biological interactions, the varying local ecologies, and microevolutionary population processes in both the biocontrol organisms and in the wasps. Recent research findings are challenging the historical perspectives on methods to manage the Sirex woodwasp, calling for management programs to incorporate the variable local dynamics affecting this pest complex. In this regard, the Sirex woodwasp provides a superb model to illustrate the need for a different approach to develop efficient and sustainable management tools to deal with the growing and global nature of pest invasions in forests and plantations.
\end{abstract}

Keywords symbiosis, population ecology, microevolution, invasion biology, biological control

\section{INTRODUCTION}

The woodwasp Sirex noctilio together with its fungal symbiont Amylostereum areolatum and a fascinating array of biological control agents, including the parasitic nematode Deladenus siricidicola, which feeds on A. areolatum, 
compose one of the most intriguing forest pest problems (99) (Supplemental

Figures 1 and 2: For all Supplemental Material, follow the link from the Annual Reviews home page at http://www.annualreviews.org). By the 1990s, researchers thought $S$. noctilio and its many associates were well understood, and management of this pest in its invasive range was considered sufficient.

Understanding of the Sirex system at that point had benefited from decades of intensive and fruitful research, mostly in Australasia (8, 71, 74, 79, 108).

However, in the subsequent two decades, $S$. noctilio continued to spread within Australia, South America, and Southern Africa, until reaching North America for the first time $(51,57)$. Despite the extensive body of knowledge regarding the management of Sirex, its spread has been characterized by variable levels of control and some devastating outbreaks (57).

\section{Sirex system: refers to the wasp and its symbionts and natural enemies}

The invasion history and impact of $S$. noctilio in different regions of the world can be clearly seen when examining the patterns of research output linked to it (a search using the term "Sirex" in the ISI Web of Science yielded 728 papers since 1913; accessed April 2014). A clear peak of activity is evident from 1960 to 1980 (217 papers), spanning the period of most intensive research in Australia and New Zealand (reviewed in 74, 108). The most significant peak in research activity, however, came after the first report of $S$. noctilio in North America in 2005 (51). Responding to the potential threat to plantations and native forest ecosystems in North America, coupled with the continuing outbreaks in new areas of Australia, South Africa, and countries of South America, research since 2005 has been the most productive to date (producing 207 papers).

This review does not repeat the details of the life history and biology of the Sirex system, which has been more than adequately treated elsewhere (see 99) (also see Supplemental Figures 1 and 2). Instead, it focuses on how recent advances in our understanding of the invasion history and the biology of the wasp, its symbionts, and its natural enemies can contribute to improved management programs. We also consider how the unique body of knowledge, the global distribution of the wasp, and the tools developed to study the Sirex system provide an outstanding model to study processes that affect the spread, 
colonization, and management of invasive forest pests and of symbioses in general (see sidebar, A Model to Study Microevolution of Invasive Pests and Biological Control).

\section{THE INVASION HISTORY OF S. NOCTILIO, A. AREOLATUM, AND D. SIRICIDICOLA}

The vertical mode of transmission of the asexual spores (arthrospores or oidia) of $A$. areolatum by $S$. noctilio results in clonality in the fungal populations. Studies using vegetative compatibility groups first revealed that siricids in Scandinavia were associated with clones of $A$. areolatum and A. chailletii and that they had spread these clones over vast areas $(110,116)$. This discovery made it possible to investigate the global spread of $S$. noctilio, as reflected by the fungal symbiont (101, 103, 114). Subsequent studies using vegetative compatibility groups, together with data from DNA sequences and PCR restriction fragment length polymorphisms, showed that a clone of the fungus had spread across three continents, presenting arguably the largest geographically spread single fungal individual ever recorded (Figure 1a). Studies to determine the possible origin of the North American introduction of $S$. noctilio combined data for six mitochondrial and nuclear loci of the fungus ( 9 , 80) and showed that the introduction had most likely occurred more than once and from different sources. Some of these North American fungal genotypes are shared with those from the Southern Hemisphere and Europe, but others are apparently unique (Figure 1a).

Arthrospores or oidia: small mycelial fragments that detach from the mycelial body

Vegetative compatibility groups: mycelium of two isolates of a fungus will fuse in culture when the alleles at incompatible loci are identical

Figure 1 Patterns of spread of (a) Sirex noctilio (blue and yellow lines) and Amylostereum areolatum (green lines), inferred from population genetic analyses, and (b) Deladenus siricidicola, inferred from recorded collections and 


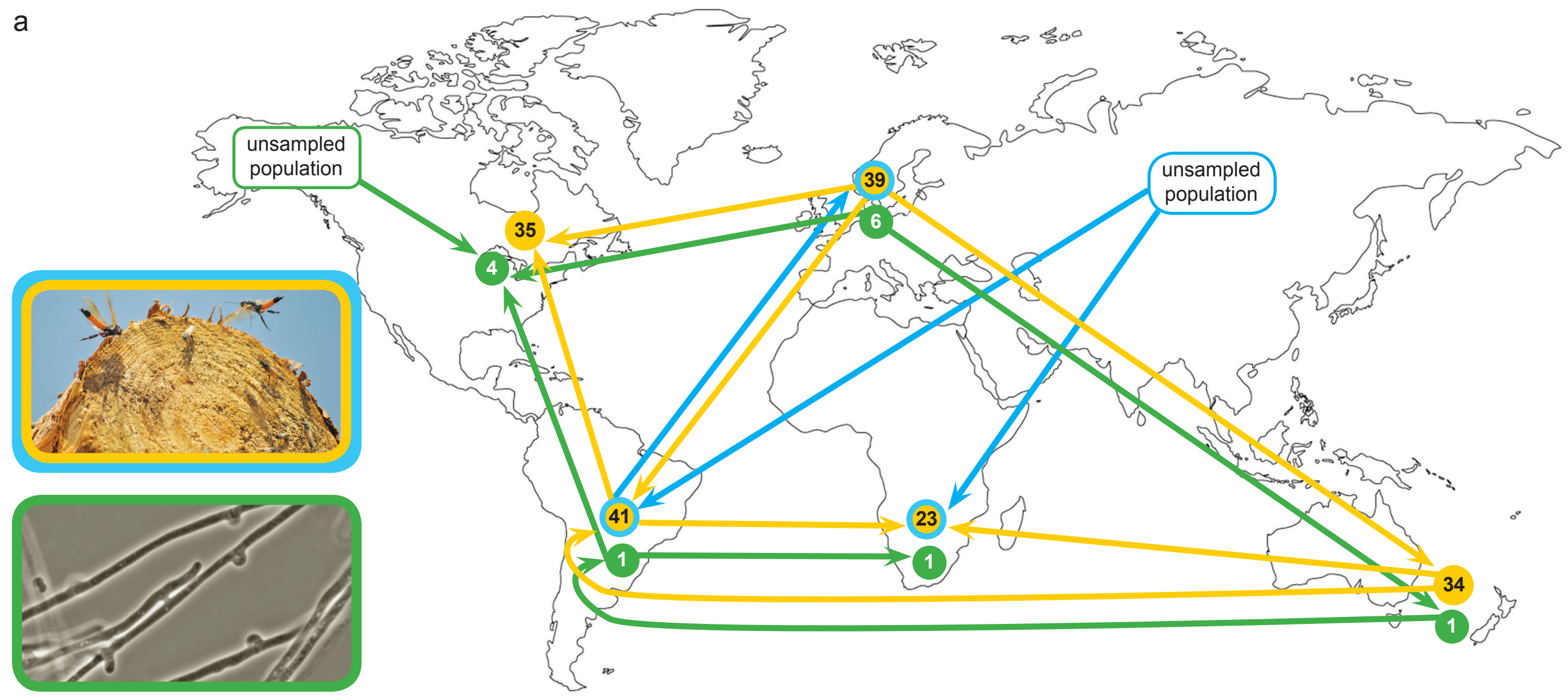

b
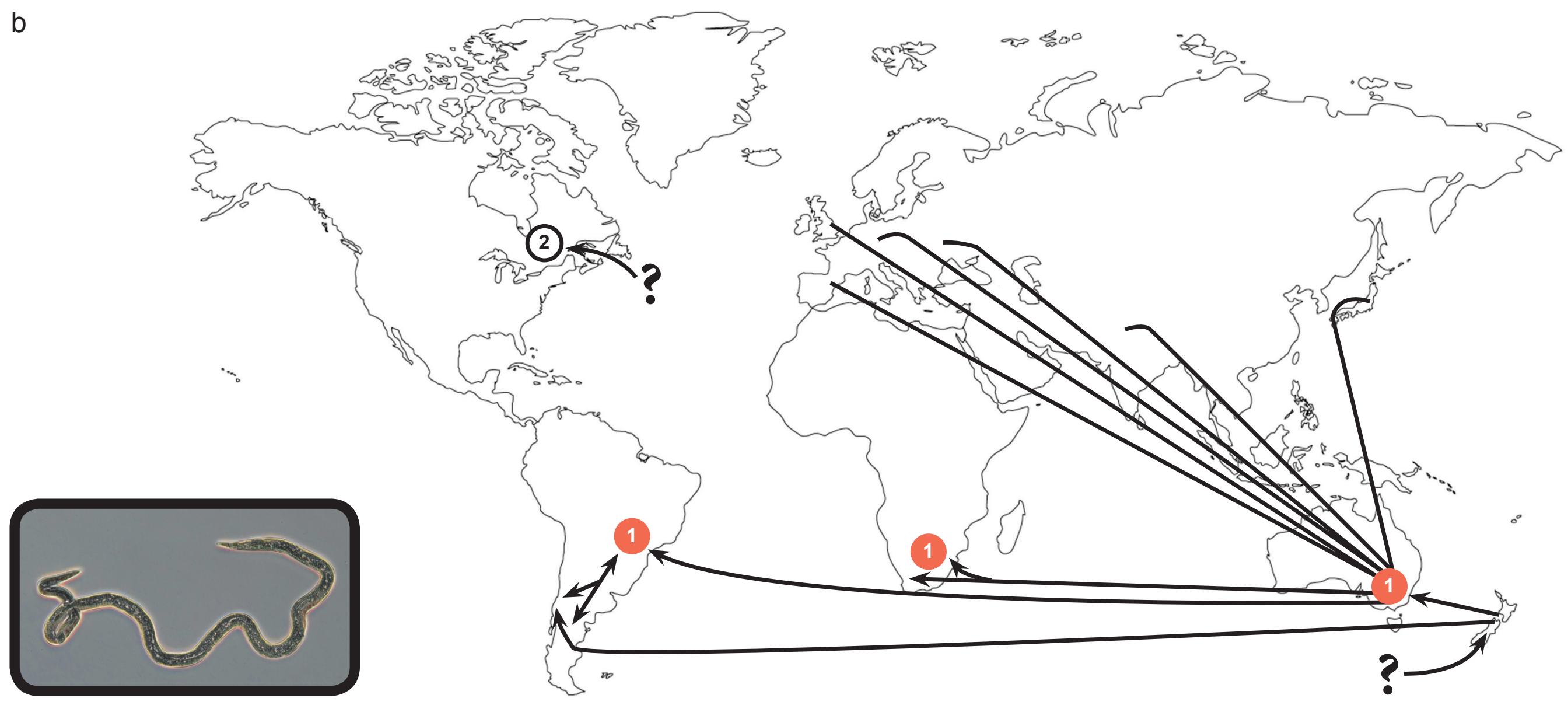
distribution of the nematode for biocontrol efforts. Numbers of genotypes are indicated in circles: The diversity of $S$. noctilio (yellow and blue circles) reflects multilocus microsatellite genotypes from 40 resampled samples from a larger collection from each region, whereas the diversity of $A$. areolatum (green circles) is based on multilocus sequence and related genotypes using restriction fragment length polymorphisms. The diversity of $(b) D$. siricidicola is based on genotypes from data using internal transcribed spacer rDNA and COI (cytochrome oxidase I) loci sequences as well as microsatellite markers. One strain (red circles), known as the Kamona strain, has been spread throughout the Southern Hemisphere as a biological control agent. The source of the introduction of the nematode into New Zealand and North America (where two different strains have been identified) is currently unknown.

The possibility that some strains of $A$. areolatum could be native to North America was first suggested when A. areolatum was identified from S. "nitidus" outside the invasive range of $S$. noctilio $(\underline{80})$. This possibility has been further supported following the isolation of $A$. areolatum from $S$. nigricornis at relatively high levels of frequency in Louisiana, which is well outside the known distribution of $S$. noctilio (81). However, A. areolatum could also have been introduced with other invasive siricid species such as $S$. juvencus (e.g., see interceptions discussed in References $\underline{18}, \underline{51}$ ), but evidence for this supposition is poor.

The most comprehensive study of the global spread of $S$. noctilio to date was based on mitochondrial COI (cytochrome oxidase I) sequence data and simple sequence repeat markers applied to the wasp (10) (Figure 1a). The data revealed a much more complex pattern of global invasion than had previously been considered. Thus, most populations of the wasp appear to be admixtures from independent introductions. These would originally have been from native regions (possibly Europe), with subsequent secondary spread among invaded regions. Importantly, two major sources or lineages were identified: one most likely from Europe, with a second of unknown origin. The source of unknown origin (outside Europe) has apparently contributed to populations in South Africa, Chile, and Switzerland. South African and South American populations also received genetic diversity from the first lineage, apparently multiple times and from multiple sources. Together with fungal data, these results reveal a complex history of introduction and reintroduction around the world, leading to admixed populations with substantial and often unique mixtures of diversity. 
The parasitic nematode Deladenus siricidicola was first discovered in populations of $S$. noctilio located in New Zealand, where it arrived without human intervention (126). In all other regions of the Southern Hemisphere, the nematode has been introduced deliberately as part of biological control programs and following extensive rearing in laboratories (Figure 1b). During the 1960s and 1970s, a number of $D$. siricidicola strains were collected from the natural range of S. noctilio, but ultimately only one (the Sopron strain, later reisolated as the Kamona strain) was selected for mass rearing and release in Australia, South America, and South Africa $(8,100)$. Mlonyeni et al. (78) showed that this has resulted in highly homozygous nematode populations across these disparate areas, most likely as a result of the repeated bottleneck and inbreeding events resulting from the transfer of relatively small numbers of genetically related nematodes during subculturing. The nematode has also recently been reported from North America $(62,65,77,125)$, where two distinct "types" have been identified on the basis of internal transcribed spacer rDNA and COI sequence data (Figure 1b).

Sopron and Kamona strains: refers to the locations in Hungary and Tasmania where $D$. siricidicola strains were isolated

\section{CHANGING PERSPECTIVES OF THE BIOLOGY OF THE SIREX SYSTEM}

Recent research considering the invasion of new areas has significantly advanced our understanding of the biology of the Sirex system. Here we consider three main areas in which such changes have occurred: $(a)$ the specificity of the symbiotic interactions, $(b)$ the diversity and roles of mutualistic and parasitic organisms, and (c) the chemical ecology of host and mate detection (Figure 2).

Figure 2 Recent insights into the biology of the Sirex system (also see Supplemental Figures 1 and 2; follow the Supplemental Materials link from the Annual Reviews home page at http://www.annualreviews.org). (a) Research into the visual and olfactory cues involved with Sirex noctilio mating and host location has confirmed the strong phototactic response of emerging wasps and identified putative pheromones, both of which contribute to the mating swarms observed above the tree canopy. This understanding, together with optimization of plant volatile (kairomone) lures, will enable researchers to develop more 
Figure 2

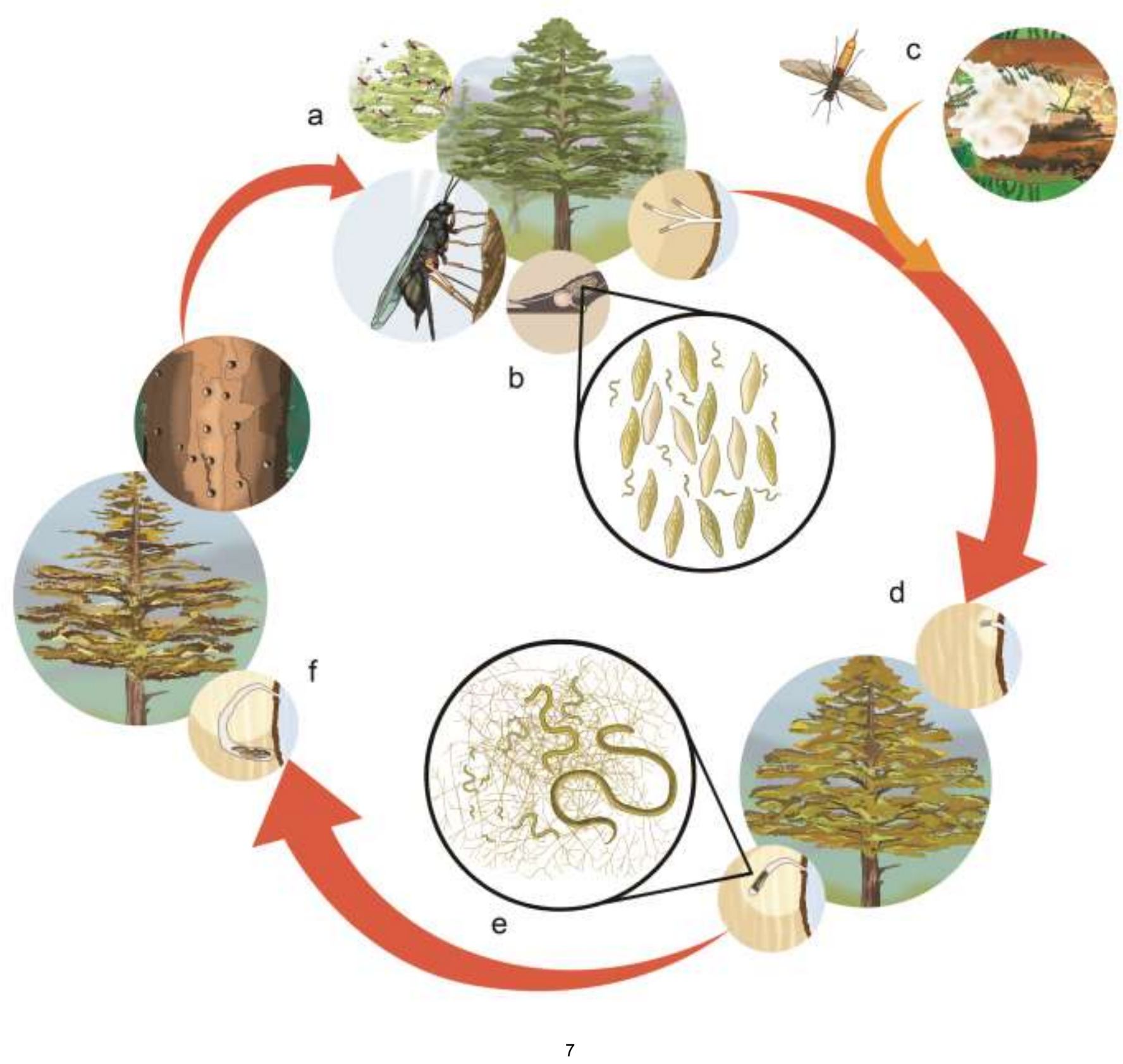


effective monitoring tools. (b) Possible evolution of resistance in S. noctilio populations or evolution of reduced virulence in nematode populations can result in incompatibility between wasp and nematode strains whereby not all eggs are penetrated by the nematode. This needs to be interpreted in terms of the introduction history and genetic diversity of the wasp and nematode populations (Figure 1). (c) Horizontal acquisition of fungal genotypes and nematode parasites could be achieved via coinfections of the pine host by other wasps or sexually produced genotypes by the fungus. $(d)$ The fungus Amylostereum areolatum decays lignin and cellulose in wood, releasing carbohydrates that are squeezed as a liquid from the wood and ingested by developing larvae. Bacteria could contribute to cellulose digestion and most likely fix nitrogen for the larvae. (e) Nitrogen is also limiting for the fungus but could be obtained from bacteria or through parasitism of the nematode. Such parasitism can potentially affect nematode population levels in the tree. $(f)$ The larvae leave the fungal colonized area during pupation, possibly to avoid parasitism.

\section{Fidelity and Specificity}

Partner uniformity, fidelity, and transmission are important when considering the evolution and stability of mutualisms $(50,61)$. In recent years, our understanding of the mutualism between Amylostereum spp. and siricids has changed dramatically in this regard. Earlier literature describes the relationship as species specific, with uniparental (female), vertical transmission of (asexual) genotypes between wasp generations (reviewed in 98, 114). The fact that there is little evidence for cospeciation between siricids and Amylostereum spp.

(Amylostereum spp. are shared among siricid genera and species), however, suggests that horizontal transmission occurs, at least at longer evolutionary timescales $(98,107,114,115)$. A similar process occurs in the related woodwasp Xiphydria and its associated xylariaceous fungi, whose genotypes are exchanged frequently (82).

\section{Cospeciation: parallel speciation in the symbiont and host, evident in congruent molecular phylogenies}

Fidelity: a process wherein a genetically identical symbiont is transmitted directly or vertically between generations of the host

\section{Vertical transmission of symbionts: direct sharing of a symbiont between generations of the wasp}

Direct evidence for horizontal transmission of symbionts between siricid individuals and species has been lacking until very recently. Independent studies 
have now shown that $S$. nigricornis, a native North American species that is normally associated with $A$. chailletii, can acquire $A$. areolatum in its mycangia $(49,81,120)$. One clone (determined through analysis of vegetative compatibility groups) was found in S. noctilio and S. nigricornis individuals emerging from the same tree (120) (Figure 2). A reciprocal, albeit apparently less common acquisition of $A$. chailletii by $S$. noctilio, has also been found (120). Accordingly, specificity for Amylostereum spp. is not an evolved trait in these siricid species. The dominance of one fungal species associated with a wasp species has likely been influenced by either geographic ranges or differences in host tree preferences.

Horizontal transmission of symbionts: genotypes of the symbiont are exchanged between unrelated individuals or species of the host Mycangia: two specialized, internal sac-like structures at the base of the ovipositor in Sirex females that contain propagules of an Amylostereum species

Early work on the distribution and ability of Deladenus spp. to feed on different Amylostereum spp. suggested that this relationship is species specific (7). Therefore, the infection of siricid species, believed to have specific associations with Amylostereum spp., was also assumed to be species specific. Morris et al. (77), however, showed that $D$. siricidicola could infect $S$. nigricornis, even when it carries $A$. chailletii. They further showed that $D$. proximus is able to infest $S$. noctilio that normally carries $A$. areolatum. However, despite lack of specificity, phylogenetic analysis showed cospeciation over longer time periods between the North American wasps and nematodes sampled (77). Nonnative $S$. noctilio apparently disrupts these coevolutionary relationships.

Bedding (6) reported that egg parasitism is specific to wasp and nematode populations. For example, a Belgian strain of the nematode did not sterilize Belgian S. noctilio but did sterilize Australian S. noctilio. Though long ignored, population-level wasp-nematode interaction specificity is reemerging as important in the context of $S$. noctilio control. In North America, for example, recent studies show that $D$. siricidicola does not enter and sterilize the eggs of $S$. noctilio $(62,77,125)$ (Figure 2). These same North American strains, however, 
sterilize South African S. noctilio (B. Slippers, personal observation). Apart from killing the host, the nematode also has indirect impacts on the fitness of the wasp population, such as female size, fecundity, and energy reserves, which are likely strain specific $(8, \underline{8}, \underline{62})$.

Deladenus spp. appears to be specific to Amylostereum (7). For practitioners working with these nematodes in culture, anecdotal evidence suggested that $D$. siricidicola might even prefer certain strains of $A$. areolatum. Relative to a strain isolated from S. noctilio in South Africa, however, Hurley et al. (55) showed equivalent developmental rates and reproduction of $D$. siricidicola on a laboratory strain of $A$. areolatum that originated from $S$. juvencus in Hungary and had been used to rear the nematode for the past three decades. In contrast, Morris et al. (76) found very significant (100-fold) differences between development on D. siricidicola on the same laboratory strain and four strains of the fungus from the United States.

\section{Nutrition and Modes of Interaction}

Siricid symbioses have long been seen as bipartite mutualistic associations with Amylostereum fungi that enable developing larvae to access nutrients in wood, particularly through cellulose digestion $(63,70,72,108)$ (Figure 2). Although other microbes are also present in galleries of siricids (69), their role in the biology of the wasp was unclear. Researchers have yet to determine the extent to which the fungus serves as nutrient source for the larvae (mycetophagy) (as has been postulated since 1942) and how it contributes to wood digestion.

\section{Mycetophagy: deriving the majority of nutrition from feeding on fungi}

Thompson et al. (112) have shown that phytosterols (from pine) and not ergosterol (from Amylostereum) dominate S. noctilio tissues, suggesting that the woody substrate makes up the majority of the larval diet. A follow-up study showed that $S$. noctilio mandibles are adapted to extract liquid from wood fragments scraped from the walls of the larval tunnels (113). Wood fragments are then discarded and moved underneath the body to be packed behind the larvae, rather than through the digestive tract. The larvae concentrate their feedings at the edges of the fungus-colonized wood, where enzymatic 
degradation would be most active, leaving the fungus-colonized area for pupation after the eighth instar (Figure 2). These studies favor an "external rumen hypothesis" in which plant molecules are digested externally by the fungus, after which the larvae feed on released starch and sugars in the extracted liquid. S. noctilio may also contribute either externally or internally to this cellulose digestion, as has been found in other insects (36).

Recent work has shown that bacteria may also play a role in cellulose digestion in Sirex galleries $(2,109)$. Adams et al. (2) identified six clades of cellulose-degrading Streptomyces and Gammaproteobacteria associated with $S$. noctilio in the United States, although they were not found consistently together with all larvae. These studies suggest that these highly efficient lignocellulosedegrading bacteria may complement the cellulose-degrading ability of the fungus. In addition, some of the sterols obtained by $S$. noctilio could be bacterial derived (113).

Apart from having a possible role in cellulose digestion and providing certain sterols, bacteria could be involved in fixing nitrogen. Dead wood is a very poor source of available nitrogen, and microbes are commonly involved in fixing nitrogen in symbioses with insects and fungi that rely on this substrate (e.g., 36, 47, 52). Contemporary analyses suggest that such associates are involved in the Sirex life cycle (111; B. Thompson, personal communication). Understanding this crucial aspect of the nutrition of $S$. noctilio will be important in gaining a more comprehensive understanding of the ecology of the Sirex system.

A recent and important advance in our understanding of the biology of Sirex symbionts has been the unexpected discovery of the apparent parasitism of $D$. siricidicola by $A$. areolatum (75) (Figure 2). Morris (75) showed that nematode reproduction in both $D$. siricidicola and $D$. proximus can be negatively affected by a unique mechanism of parasitism of adults and eggs by Amylostereum. This discovery provides a possible explanation why Deladenus does not survive in culture when Amylostereum is fast growing or when the ratio of nematodes to fungus is inordinately biased toward the fungus ( 8 ). The emergence of this form of parasitism makes evolutionary sense, given that it could positively affect the fitness of both the fungus and the wasp (through possible reduction in parasitism). This factor will be important to consider in biological control programs. 


\section{Chemical Ecology}

It is a long-recognized fact that $S$. noctilio is attracted to the stems of stressed pine trees $(95,96)$ (Figure 2). A large number of volatile compounds $(>60)$ are associated with such pine stems, with the bulk of these made up of monoterpene hydrocarbons (>95\%) such as $\alpha$ - and $\beta$-pinene $(29,95,96)$. Until 2004, researchers in Australia had exploited this knowledge for lure-based trapping of S. noctilio (5). Much work has recently been expended to refine these lures, and complex blends of up to six different compounds are now used $(29,53)$. A twocomponent lure of $\alpha$ - and $\beta$-pinene is, however, most widely used in the United States and Canada to monitor S. noctilio populations (32) as well as to study native wasps (e.g., seven native siricids in Minnesota) (28). Böröczky et al. (15) further examined the role of host volatiles and found that trees that produced greater amounts of volatiles, specifically careen, trapped more wasps.

Investigators are beginning to acquire promising knowledge regarding pheromones linked to $S$. noctilio biology. Soon after emergence, both wasp sexes fly up to the forest canopy, where they aggregate in male-dominated swarms (71; B. Slippers, personal observation) (Figure 2). Research has determined that the original signal after emergence is phototactic (see 94), after which either visual (light, structure above the canopy, other wasps and their coloration) or olfactory cues (pheromones) could direct wasp behavior. The male and female antennal sensilla have many contact chemoreceptors (30). Consistent with this fact, Böröczky et al. (14) isolated three nonvolatile cuticular hydrocarbon compounds from female wasps that elicited a mating response from males at short (contact) range. More recently, researchers have isolated from around groups of male wasps three unsaturated alcohol compounds, which could act as longer-range volatile pheromones (23). Although these compounds showed promise in experiments using gas chromatography electroantennal detection as well as Y tubes, they failed to catch wasps in field trials (54), perhaps because of the wasp's strong phototactic response (94).

\section{Pheromone: chemicals produced by individual organisms that affect the behavior of other members of its species}


The detection of Amylostereum volatiles by S. noctilio has been poorly studied. The ability to detect Amylostereum volatiles appears to have evolved in parallel in Xeris species (Siricidae) (43) and two parasitoid lineages (Ibalia leucospoides, I. drewseni, and Rhyssa spp.) (17, 67, 73, 104, 105). Because Amylostereum volatiles would indicate a substrate that is suitable for larval development, their detection by other siricids makes evolutionary sense. Such detection would also serve to enhance horizontal acquisition of fungal strains (Figure 2). Despite the above-mentioned recent efforts, details of the kairomone and pheromone cues that influence host-finding and mating behavior of the siricid woodwasp remains obscure; this field presents exciting opportunities.

\section{POPULATION DYNAMICS AND MANAGEMENT}

Subsequent to the first outbreaks of $S$. noctilio more than 60 years ago, a major focus of research is the factors that influence population dynamics and that might provide the keys to managing population outbreaks. The bulk of this work has been done in Australasia, and the simplistic notion that management tools could be easily transferred to other regions has slowed down local adaptation of management programs and has also led to variable control results in various parts of the world $(56,57,102,117)$. In this section, we consider the emerging challenges and opportunities linked to four main factors affecting $S$. noctilio population fluctuations: its natural enemies, the pine host, the wasp, and cooccurring organisms (Figure 3).

Figure 3 Factors that do or may influence Sirex noctilio population dynamics and that have implications for the development of management strategies.

\section{Natural Enemies}

Top-down control of $S$. noctilio populations by its natural enemies is considered to be one of the most important tools for active management of this pest in invaded nonnative pine plantations $(\underline{8}, \underline{20}, \underline{57}, \underline{71})$. This also plays an important role in populations in natural woody ecosystems $(\underline{4}, \underline{27}, \underline{37}, \underline{66}, \underline{90}, \underline{106}, \underline{128})$. Despite the existence of a large body of literature, substantial gaps in our knowledge remain to be filled to improve management systems using natural enemies in many invaded regions of the world. 


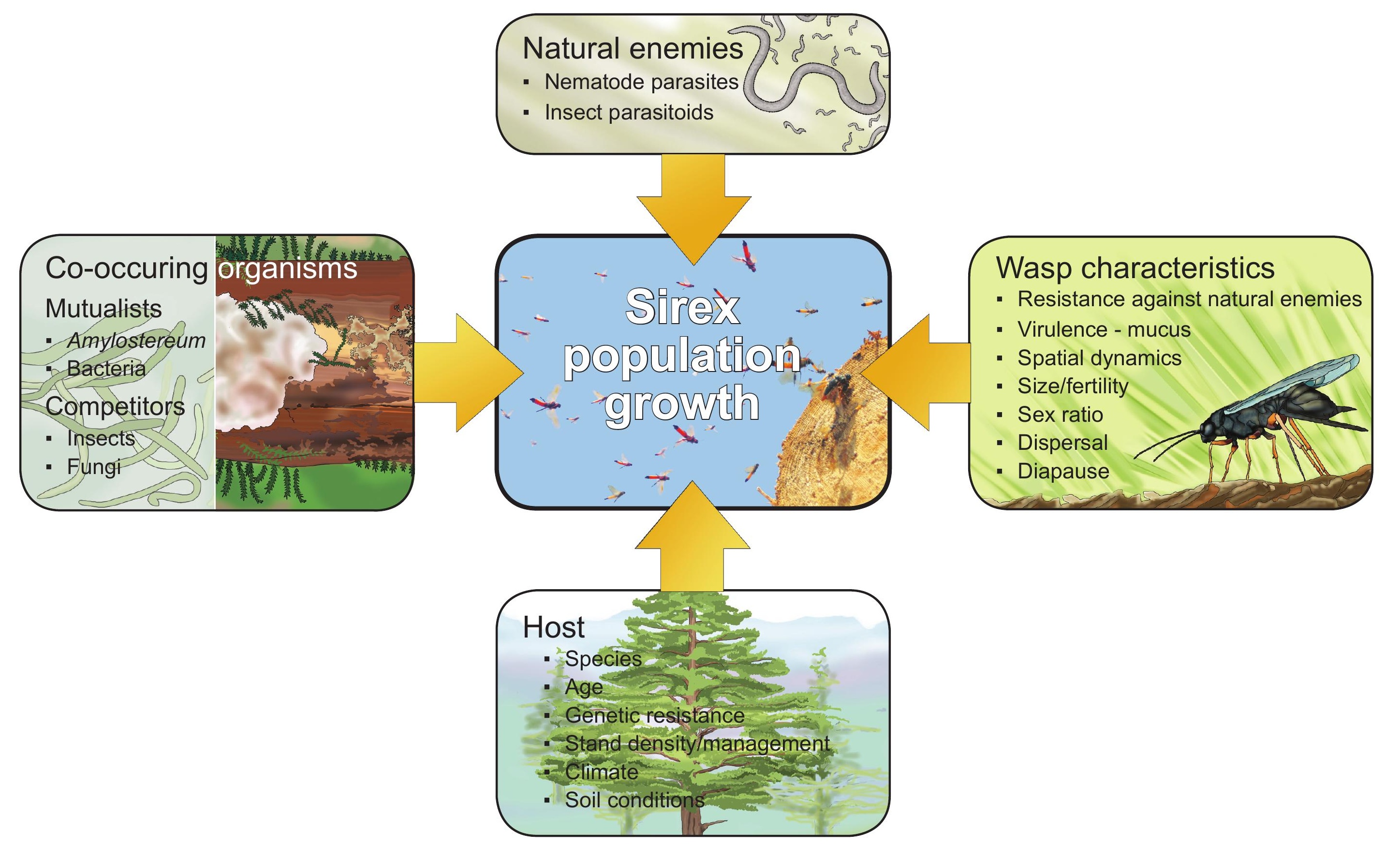


Numerous parasitic wasp species (Ibalia, Megarhyssa, Rhyssa, and Schlettererius species) have been introduced into Australasia for the biological control of $S$. noctilio $(19,20,57)$. These insects, however, remain patchily distributed in other areas of the world. This is unfortunate, as these parasitoid species are important at different densities of $S$. noctilio and in different environments $(19,20)$. Ibalia leucospoides has been the most widely used of these parasitoids. Yet, even for this species, recent data on dispersal ability (which is half that of $S$. noctilio), feeding, the cost of long-distance dispersal, and constraints on host location suggest that a reevaluation of methods of rearing, spread, and the potential of augmentative releases is required $(26, \underline{38}, \underline{39}, \underline{40}, \underline{83})$. Furthermore, the diversity of these parasitoids is poorly understood, despite its potential importance for understanding and managing adaptability of parasitoid populations (e.g., see $\underline{85}, \underline{86})$.

Reduction of diversity through human selection and inbreeding in serial culture has had a substantial influence on populations of D. siricidicola (78), which is widely considered to be the most important natural enemy of the wasp. The threat of such a narrow genetic base became abundantly evident during the Australian "Green Triangle" outbreak, when the nematodes used in biocontrol programs lost their virulence in culture (). . Other consequences of extreme selection processes and the lack of nematode diversity have, however, rarely been considered (e.g., 85, 86). In light of emerging knowledge regarding diversity of global $S$. noctilio populations and the specificity of nematode-wasp and nematode-fungus interactions (discussed above), such factors can significantly affect the success of biological control. For example, Slippers et al. (100) speculated that variation in infection levels could reflect a possible evolution of resistance in $S$. noctilio populations or, alternatively, the evolution of reduced virulence in the nematode. The latter option would be influenced by a trade-off between transmission efficiency inside and outside the eggs and host availability in the next generation (Supplemental Table 1).

Virulence: in the Sirex system, reflects reduced or an absence of sterilization of eggs

Resistance: in the Sirex system, includes the ability to resist initial infection or the infection of eggs 
The Southern Hemisphere (Kamona) strain of $D$. siricidicola has been considered for management of the S. noctilio invasion in North America (119). The recent discovery of $A$. areolatum associated with native siricid species, as well as the occurrence of other strains of this nematode species in North America, appears to make this an unnecessary risk $(62,65,77,125)$. A suite of other natural enemies associated with native siricids is also attacking $S$. noctilio in North America (4, 27, 37, 66, 128). Thus, additional biological control, at least given the current distribution of the wasp, seems unnecessary (32). A renewed focus on the natural enemies of $S$. noctilio in North America promises to reverse a long period when this subject received little attention. In addition, researchers now have access to these enemies in their native range and may be able to use them in other regions of the world.

\section{Pine Host}

S. noctilio is a secondary pest that attacks only stressed or dying trees $(\underline{4}, \underline{12}, \underline{68}$, 106). Managing stress is thus important in efforts to manage Sirex $(20,31,71)$. However, the economics of plantation management and unpredictability of stresses arising from variable climate, fire, and biotic factors results in damaging outbreaks of the pest that often cannot be predicted (53). For this reason, it is important to monitor vulnerable plantations and to maintain an understanding of developing outbreaks. A suite of recent studies has pursued these objectives through the use of remote sensing tools, which have become increasingly accurate $(1,58,59)$. These studies have also made it possible to identify local stress factors such as sites with rapid soil moisture evapotranspiration as well as intermittent rainfall that influence $S$. noctilio susceptibility (60).

$S$. noctilio infests a wide range of Pinus species across its global distribution $(12,91)$. The comparative susceptibility of these Pinus spp. is poorly understood, possibly because large areas in the Southern Hemisphere are typically dominated by monocultures of a particular Pinus species. In Europe and North America, however, where mixed stands of native Pinus spp. are more common, European Pinus species are generally preferred to North American species (4, 33). Ayres et al. (4) observed that $P$. radiata, which is commonly attacked in the Southern Hemisphere, is not a preferred species in the native range of $S$. noctilio. Thus, 
when there is no or limited choice of host, wasp populations can reach very high population levels on Pinus species that are less favored.

Resistance to $S$. noctilio infestation in Pinus spp. and the response of these trees to infection by $A$. areolatum have never been directly considered in breeding programs, even though researchers know that mechanisms that contribute to resistance have a genetic basis (e.g., resin production, ethylene, and polyphenol production) (11--13). Owing to the availability of alternative control measures, resistance breeding has been given low priority. An improved understanding of the volatile and resin profiles of susceptible hosts (e.g., 13), the genetics and biochemistry linked to the interactions between Pinus and Sirex mucus (venom) injected into trees at the time of egg laying (11), and the clonality of $A$. areolatum associated with some invasive populations (101) could provide better targets for resistance breeding in future.

\section{Wasp}

Various aspects of the life history of $S$. noctilio can dramatically influence its population dynamics (reviewed in 24, 91, 117) (Figure 3). These factors include fecundity, reproductive potential, adult size, sex ratio, and the influence of diapause on the length of the larval period (1--3 years). All these factors vary significantly within and between wasp populations, yet the extent of variation and the mechanisms controlling them remain very poorly understood. Aparacio et al. (3) suggest these factors alone may explain wasp outbreaks, independent of environmental factors.

Sex ratios in S. noctilio vary dramatically among populations, ranging from one or two males per female to more than 20 males per female $(91,106)$. Very high male to female ratios are often attributed to the haplodiploid reproductive system and Allee effects such as mate finding in invading or expanding populations. But many of these skewed ratios persist despite high population numbers (e.g., greater than $\sim 10: 1$ in eastern parts of South Africa over many years) (56). The importance of sex ratio on reproductive potential, ability to overcome host defenses, and dispersal has begun to drive research initiatives to explore possible influencing factors, including, for example, endosymbionts, resource quality variation, and genetic mechanisms such as a reduced diversity at sex determining loci. 
Haplodiploid: most hymenoptera produce haploid males from unfertilized eggs and diploid females from fertilized eggs

Allee effects: effects that reduce individual fitness at low population densities

The spatial dynamics, including both aggregation and flight potential, of $S$. noctilio populations represent important issues in understanding the development and spread of outbreaks $(16,24,25,64,117)$. Such studies showed increasing spatial aggregation under preoutbreak and outbreak conditions, which became less evident as the outbreak developed $(25,117)$ (Supplemental Table 1). The aggressiveness of $S$. noctilio increases with density: It primarily attacks stressed trees (4) but then can overcome the defenses of healthy trees under outbreak conditions (25). Beyond the stand level, spatial dynamics are significantly affected by flight potential $(16,24,25)$. Lantschner et al. (64) calculated that $S$. noctilio spreads between $12 \mathrm{~km}$ (Argentina) and $78 \mathrm{~km}$ (eastern part of South Africa) per year; the spread rate best correlates with mean annual temperature and isothermality. Temperature also has a major impact on phenology and, consequently, on the management of Sirex in different environments $(48,91)$.

Resistance to infection by specific nematode strains exists in some S. noctilio populations $(6,62,100,125)$ (also see above discussion). Because various factors may have been involved in the steady decline in nematode parasitism in some parts of Australia (20), development of resistance in the wasp should be investigated in this region as well as in other parts of the world. Understanding which factors may influence the development of such resistance relates directly to the evolution of invasive species and biological control more broadly (see 85 , 86) (Supplemental Table 1).

\section{Co-Occurring Organisms}

Other than the mutualistic interactions between $S$. noctilio and various microorganisms, many xylophagous insects can be found in the trunks of $S$. noctilio--infested trees. Such insects may interact with S. noctilio either directly or indirectly by introducing competing fungi $(4,88,92,118,124)$. A. areolatum is a weak competitor against certain fungi that occur as endophytes in Pinus (e.g., Diplodia sapinea in South Africa) or that are introduced by bark beetles in North America and Australia (e.g., Ophiostoma ips introduced by Ips 
grandicollis and Leptographium wingfieldii by Tomicus piniperda) $(55,92,124$, 127). These fungi can affect the rate at which trees die and the wood moisture levels in infested trees, which has indirect negative effects on A. areolatum (124) and on the oviposition behavior of the wasp (89). Apart from their competition with $A$. areolatum, competing insects can also interfere with management programs $(28, \underline{34}, \underline{35}, \underline{45}, \underline{46}, \underline{124}, \underline{127})$. In Australia, for example, colonization of dying trees by I. grandicollis reduces the number of $S$. noctilio oviposition events, the size of $S$. noctilio individuals in trap trees, and the level of parasitism of the wasp by $D$. siricidicola (124). Despite these potential influences on $S$. noctilio infestations, especially in the case of trap trees, data collected by Ayres et al. (4) suggest competing organisms were not a major limiting factor in host use by $S$. noctilio in Spain and the United States.

\section{CONCLUSIONS}

The history of the global spread of $S$. noctilio reflects a complex pattern of introductions that have occurred multiple times and from numerous different sources. The likelihood that these introductions will continue represents a significant threat for currently unaffected Pinus forests and plantations in Africa, Australia, South America, parts of Asia (e.g., Japan), and North America (for potential distribution and risk analysis, see 21,121 ). Continued accidental introductions of $S$. noctilio are also likely to further contribute to admixture and the potential for evolution and spread of resistance to the nematode in these populations. For these reasons, quarantine remains critically important even in countries where the wasp is well established. Importantly, this calls for the development of more effective monitoring and detection tools as well as for the enhancement of risk analyses $(\underline{54}, \underline{60}, \underline{73 a}, 122,123)$.

The appearance of $S$. noctilio in North America has mobilized research capacity and investment on a pest that had been relatively poorly studied. Its appearance has also provided a fascinating opportunity to study an alien invasive pest in an environment very similar to its native habitat. Furthermore, renewed research provides an opportunity to challenge as well as to transform our understanding of the Sirex system. Much remains to be learned about the ecology of the multiple components of mutualistic and parasitic interactions that either 
facilitate or restrict the development of $S$. noctilio populations. Substantial new insights are likely to arise from comparative studies across systems in different parts of the world, as has been well illustrated in recent studies on the spread, biology, and ecology of the wasp $(4,10,21,64)$. Such information will be invaluable in the quest to refine and sustain management programs around the world.

The patterns of continued, complex, and increasingly rapid rates of introduction are not unique to $S$. noctilio but, unfortunately, represent a general trend for many invasive species $(41,84,87,93,97)$. All findings indicate that we face a future with much greater pressure due to a diversity of pests in natural woody ecosystems and in planted forests. As a result, to maintain the sustainability of forests and plantations, management programs will be under significantly greater pressure to develop more rapidly and yield greater impact. On the basis of our experience with the Sirex system, we suggest two areas in particular need of change. First, more robust international cooperative networks are needed to share information, experience, and tools, including biological control agents, for pest management (see 44). Moreover, these networks will need to be implemented more rapidly than they have in the past. Second, management programs will need to be refined to ensure their stability and impact, thus requiring a deeper understanding of the mechanisms that influence the success of both the invader pests and biological control agents at local levels. In this regard, the $S$. noctilio system serves as an outstanding model of a globally important and biologically complex invasive system. The lessons learned from understanding and dealing with it will contribute substantially to managing the health of future forests and plantations.

\section{SUMMARY POINTS AND FUTURE DIRECTIONS}

1. S. noctilio has continued to spread despite quarantine systems. Thus, we must prepare for further introductions, and reintroductions, of the wasp, including those from nonnative to native areas.

2. There is an urgent need to refine chemical and remote sensing tools to monitor and quantify populations of $S$. noctilio. 
3. Complex patterns of interaction at varying levels of specificity among $S$. noctilio, $A$. areolatum, bacteria, competing insects and fungi, and the tree host and its natural enemies facilitate or restrict population growth of S. noctilio.

4. Classical biological programs such as those applied to $S$. noctilio need continuous monitoring and refinement. They are likely to require knowledge of local ecology, diversity, and microevolution for successful transfer between regions.

5. There are both an opportunity and a need for international comparative studies, including in native and various nonnative habitats, to characterize factors that influence invasion and local population ecology.

6. More refined knowledge of the genetics, biochemistry, and chemical ecology of $S$. noctilio and the many organisms associated with this wasp will contribute to opportunities to breed and select trees with resistance to this pest.

7. The Sirex system reflects similar processes in other invasive pests and thus represents an outstanding model to study the evolution of an invasive forest pest, its biological control, and the many fascinating aspects of the ecology and evolution of symbioses.

\section{DISCLOSURE STATEMENT}

The authors are not aware of any affiliations, memberships, funding, or financial holdings that might be perceived as affecting the objectivity of this review.

\section{ACKNOWLEDGMENTS}

We are grateful to Glenda Brits for providing artwork, Dr. Jeff Garnas for helpful comments on the manuscript, and Osmond Mlonyeni for providing the nematode photograph used in Figure $1 b$. We acknowledge financial support from the members of the Tree Protection Co-operative Program, DST/NRF Center of Excellence in Tree Health Biotechnology, and the University of Pretoria. 


\section{LITERATURE CITED}

1. Abdel-Rahman EM, Mutanga O, Adam E, Ismail R. 2014. Detecting Sirex noctilio grey-attacked and lightning-struck pine trees using airborne hyperspectral data, random forest and support vector machines classifiers. ISPRS J. Photogramm. Remote Sens. 88:48--59

2. Adams AS, Jordan MS, Adams SM, Suen G, Goodwin LA, et al. 2011. Cellulosedegrading bacteria associated with the invasive woodwasp Sirex noctilio. ISME J. $5: 1323--31$

3. Aparacio JP, Corley JC, Rabinovich J. 2013. Life history traits of Sirex noctilio F. (Hymenoptera: Siricidae) can explain outbreaks independently of environmental factors. Math. Biosci. Eng. 10:1265--79

4. Ayres MP, Pena R, Lombardo JA, Lombardero MJ. 2014. Host use patterns by the European woodwasp, Sirex noctilio, in its native and invaded range. PLOS ONE 9:e90321

5. Bashford R, Madden JL. 2012. The use of kairomone lures for the detection of Sirex noctilio in susceptible Pinus radiata plantations in Australia. See Ref. 99, pp. $159--66$

6. Bedding RA. 1972. Biology of Deladenus siricidicola (Neotylenchidae) an entomophagous-mycetophagous nematode parasitic in siricid woodwasps. Nematologica 18:482--93

7. Bedding RA, Akhurst RJ. 1978. Geographical distribution and host preferences of Deladenus species (Nematoda: Neotylenchidae) parasitic in siricid woodwasps and associated hymenopterous parasitoids. Nematologica 24:286--94

8. Bedding RA, Iede ET. 2005. Application of Beddingia siricidicola for Sirex woodwasp control. In Nematodes as Biocontrol Agents, ed. PS Grewal, R-U Ehlers, DI Shapiro-Ilan, pp. 385--99. London: CABI

9. Bergeron MJ, Leal I, Foord B, Ross G, Davis C, et al. 2011. Putative origin of clonal lineages of Amylostereum areolatum, the fungal symbiont associated with Sirex noctilio, retrieved from Pinus sylvestris, in eastern Canada. Fungal Biol. 115:750--58

10. Boissin E, Hurley B, Wingfield MJ, Vasaitis R, Stenlid J, et al. 2012. Retracing the routes of introduction of invasive species: the case of the Sirex noctilio woodwasp. Mol. Ecol. 21:5728--44 
11. Bordeaux JM. 2014. Isolation and structural characterization of the active molecule from Sirex noctilio woodwasp venom inducing primary physiological symptoms in attacked pine species. PhD thesis. Univ. Georgia, Athens

12. Bordeaux JM, Dean JFD. 2012. Susceptibility and response of pines to Sirex noctilio. See Ref. 99, pp. 31--50

13. Bordeaux JM, Lorenz WW, Dean JFD. 2012. Biomarker genes highlight intraspecific and interspecific variations in the responses of Pinus taeda L. and Pinus radiata D. Don to Sirex noctilio F. acid gland secretions. Tree Physiol. 32:1302--12

14. Böröczky K, Crook DJ, Jones TH, Kenny JC, Zylstra KE, et al. 2009. Monoalkenes as contact sex pheromone components of the woodwasp Sirex noctilio. J. Chem. Ecol. 35:1202--11

15. Böröczky K, Zylstra KE, McCartney NB, Mastro VC, Tumlinson JH. 2012. Volatile profile differences and the associated Sirex noctilio activity in two host tree species in the Northeastern United States. J. Chem. Ecol. 38:213--21

16. Bruzzone OA, Villacide JM, Bernstein C, Corley JC. 2009. Flight variability in the woodwasp Sirex noctilio (Hymenoptera: Siricidae): an analysis of flight data using wavelets. J. Exp. Biol. 212:731--37

17. Bryant PB. 2010. Kairomonal attraction of the parasitoid Ibalia leucospoides (Hymenoptera: Ibaliidae) to volatiles of the fungus Amylostereum areolatum, an obligate symbiont of the European woodwasp, Sirex noctilio. MSc thesis. State Univ. New York, Syracuse

18. Burnip GM, Voice D, Brockerhoff EG. 2010. Interceptions and incursions of exotic Sirex species and other siricids (Hymenoptera: Siricidae). N.Z. J. For. Sci. 40:133--40

19. Cameron EA. 2012. Parasitoids in the management of Sirex noctilio: looking back and looking ahead. See Ref. 99, pp. 103--18

20. Carnegie AJ, Bashford R. 2012. Sirex woodwasp in Australia: current management strategies, research and emerging issues. See Ref. 99, pp. 175--201

21. Carnegie AJ, Matsuki M, Haugen DA, Hurley BP, Ahumada R, et al. 2006. Predicting the potential distribution of Sirex noctilio (Hymenoptera: 
Siricidae), a significant exotic pest of Pinus plantations. Ann. Forest Sci. 63:119--28

22. Clark TA, Anderson JB. 2004. Dikaryons of the basidiomycete fungus Schizophyllum commune: evolution in long-term culture. Genetics 167:1663--75

23. Cooperband MF, Böröczky K, Hartness A, Jones TH, Zylstra KE, et al. 2012. Male-produced pheromone in the European woodwasp, Sirex noctilio. J. Chem. Ecol. 38:52--62

24. Corley JC, Villacide JM. 2012. Population dynamics of Sirex noctilio: influence of diapause, spatial aggregation and flight potential on outbreaks and spread. See Ref. 99, pp. 51--64

25. Corley JC, Villacide JM, Bruzzone OA. 2007. Spatial dynamics of a Sirex noctilio woodwasp population within a pine plantation in Patagonia, Argentina. Entomol. Exp. Appl. 125:231--36

26. Corley JC, Villacide JM, van Nouhuys S. 2010. Patch time allocation by a parasitoid: the influence of con-specifics, host abundance and distance to the patch. J. Insect Behav. 23:431--40

27. Coyle DR, Gandhi KJK. 2012. The ecology, behavior, and biological control potential of Hymenopteran parasitoids of woodwasps (Hymenoptera: Siricidae) in North America. Environ. Entomol. 41:731--49

28. Coyle DR, Pfammatter JA, Journey AM, Pahs TL, Cervenka VJ, Koch RL. 2012. Community composition and phenology of native Siricidae (Hymenoptera) attracted to semiochemicals in Minnesota. Environ. Entomol. 41:91--97

29. Crook DJ, Böröczky K, Zylstra KE, Mastro VC, Tumlinson JH. 2012. The chemical ecology of Sirex noctilio. See Ref. 99, pp. 149--58

30. Crook DJ, Kerr LM, Mastro VC. 2008. Sensilla on the antennal flagellum of Sirex noctilio (Hymenoptera: Siricidae). Ann. Entomol. Soc. Am. 101:1094--102

31. Dodds KI, Cooke RR, Gilmore DW. 2007. Silvicultural options to reduce pine susceptibility to attack by a newly detected invasive species, Sirex noctilio. North. J. Appl. For. 24:165--67

32. Dodds K, de Groot P. 2012. Sirex, surveys and management: challenges of having Sirex noctilio in North America. See Ref. 99, pp. 265--86 
33. Dodds K, de Groot P, Orwig DA. 2010. The impact of Sirex noctilio in Pinus resinosa and Pinus sylvestris stands in New York and Ontario. Can. J. For. Res. 40:212--23

34. Dodds KJ, Miller DR. 2010. Test of nonhost angiosperm volatiles and verbenone to protect trap trees for Sirex noctilio (Hymenoptera: Siricidae) from attacks by bark beetles (Coleoptera: Scolytidae) in the northeastern United States. J. Econ. Entomol. 103:2094--99

35. Dodds KJ, Zylstra KE, Dubois GD, Hoebeke ER. 2012. Arboreal insects associated with herbicide-stressed Pinus resinosa and Pinus sylvestris used as Sirex noctilio trap trees in New York. Environ. Entomol. 41:1350--63

36. Douglas AE. 2009. The microbial dimension in insect nutritional ecology. Funct. Ecol. 23:38--47

37. Eager PT, Allen DC, Frair JL, Fierke MK. 2011. Within-tree distributions of the Sirex noctilio fabricius (Hymenoptera: Siricidae): parasitoid complex and development of an optimal sampling scheme. Environ. Entomol. 40:1266--75

38. Fernandez-Arhex V, Corley JC. 2005. The functional response of Ibalia leucospoides (Hymenoptera: Ibaliidae), a parasitoid of Sirex noctilio (Hymenoptera: Siricidae). Biocontrol Sci. Technol. 15:207--12

39. Fischbein D, Bernstein C, Corley JC. 2012. Linking reproductive and feeding strategies in the parasitoid Ibalia leucospoides: Does feeding always imply profit? Evol. Ecol. 27:619--34

40. Fischbein D, Bettinelli J, Bernstein C, Corley JC. 2012. Patch choice from a distance and use of habitat information during foraging by the parasitoid Ibalia leucospoides. Ecol. Entomol. 37:161--68

41. Fisher MC, Henk D, Briggs CJ, Brownstein JS, Madoff LC, et al. 2012. Emerging fungal threats to animal, plant and ecosystem health. Nature 484:186--94

\section{Deleted in proof.}

43. Fukuda H, Hijii N. 1997. Reproductive strategy of a woodwasp with no fungal symbionts, Xeris spectrum (Hymenoptera: Siricidae). Oecologia 112:551--56

44. Garnas JR, Hurley BP, Slippers B, Wingfield MJ. 2012. Biological control of forest plantation pests in an interconnected world requires greater international focus. Int. J. Pest Manag. 58:211--23 
45. Gitau CW, Bashford R, Carnegie AJ, Gurr GM. 2013. A review of semiochemicals associated with bark beetle (Coleoptera: Curculionidae: Scolytinae) pests of coniferous trees: a focus on beetle interactions with other pests and their associates. For. Ecol. Manag. 297:1--14

46. Gitau CW, Carnegie AJ, Nicol HI, Bashford R, Poynter C, Gurr GM. 2013. Incidence of Ips grandicollis (Coleoptera: Scolytinae) in trap trees prepared for biological control of Sirex noctilio (Hymenoptera: Siricidae) in Australia: influence of environment and silviculture. For. Ecol. Manag. 310:865--74

47. Grünwald S, Pilhofer M, Holl W. 2010. Microbial associations in gut systems of wood- and bark-inhabiting longhorned beetles (Coleoptera: Cerambycidae). Syst. Appl. Microbiol. 33:25--34

48. Haavik LJ, Meeker JR, Johnson W, Ryan K, Turgeon JJ, Allison JD. 2013. Predicting Sirex noctilio and $S$. nigricornis emergence using degree days. Entomol. Exp. Appl. 149:177--84

49. Hajek AE, Nielsen C, Kepler RM, Long SJ, Castrillo L. 2013 Fidelity among Sirex woodwasps and their fungal symbionts. Microb. Ecol. 65:753--62

50. Herre EA, Knowlton N, Mueller UG, Rehner SA. 1999. The evolution of mutualisms: exploring the paths between conflict and cooperation. Trends Ecol. Evol. 14:49--53

51. Hoebeke ER, Haugen DA, Haack RA. 2005. Sirex noctilio: discovery of a Palearctic siricid woodwasp in New York. Newsl. Mich. Entomol. Soc. 50:24--25

52. Hoppe B, Kahl T, Karasch P, Wubet T, Bauhus J, et al. 2014. Network analysis reveals ecological links between $\mathrm{N}$-fixing bacteria and wood-decaying fungi. PLoS ONE 9:e88141

53. Hurley BP, Croft P, Verleur M, Wingfield MJ, Slippers B. 2012. The control of the Sirex woodwasp in diverse environments: the South African experience. See Ref. 99, pp. 247--64

54. Hurley BP, Garnas J, Cooperband M. 2014. Assessing trap and lure effectiveness for the monitoring of Sirex noctilio. Agric. For. Entomol. Epub ahead of print; doi: 10.1111/afe.12081

55. Hurley BP, Hatting HJ, Wingfield MJ, Klepzig KD, Slippers B. 2012. The influence of Amylostereum areolatum diversity and competitive interactions on the fitness of the Sirex parasitic nematode Deladenus siricidicola. Biol. Control 61:207--14 
56. Hurley BP, Slippers B, Croft PK, Hatting HJ, van der Linde M, et al. 2008. Factors influencing parasitism of Sirex noctilio (Hymenoptera: Siricidae) by the nematode Deladenus siricidicola (Nematoda: Neotylenchidae) in summer rainfall areas of South Africa. Biol. Control 45:450--59

57. Hurley BP, Slippers B, Wingfield MJ. 2007. A comparison of control results for the alien invasive woodwasp, Sirex noctilio, in the southern hemisphere. Agr. Forest Entomol. 9:159--71

58. Ismail R, Mutanga O. 2011. Discriminating the early stages of Sirex noctilio infestation using classification tree ensembles and shortwave infrared bands. Int. J. Remote Sens. 32:4249--66

59. Ismail R, Mutanga O, Bob U. 2007. Forest health and vitality: the detection and monitoring of Pinus patula trees infected by Sirex noctilio using digital multispectral imagery. South. Hemisph. For. J. 69:39--47

60. Ismail R, Mutanga O, Kumar L. 2010. Modeling the potential distribution of pine forests susceptible to Sirex noctilio infestations in Mpumalanga, South Africa. Trans. GIS 14:709--26

61. Korb J, Aanen DK. 2003. The evolution of uniparental transmission of fungal symbionts in fungus-growing termites (Macrotermitinae). Behav. Ecol. Sociobiol. 53:65--71

62. Kroll SA, Hajek AE, Morris EE, Long SJ. 2013. Parasitism of Sirex noctilio by non-sterilizing Deladenus siricidicola in northeastern North America. Biol. Control 67:203--11

63. Kukor JJ, Martin MM. 1983. Acquisition of digestive enzymes by siricid woodwasps from their fungal symbiont. Science 220:1161--63

64. Lantschner MV, Villacide JM, Garnas JR, Croft P, Carnegie AJ, et al. 2014. Temperature explains variable spread rates of the invasive woodwasp Sirex noctilio in the Southern Hemisphere. Biol. Invasions 16:329--39

65. Leal I, Foord B, Davis C, de Groot P, Mlonyeni XO, Slippers B. 2012. Distinguishing isolates of Deladenus siricidicola, a biological control agent of Sirex noctilio, from North America and the Southern Hemisphere using PCRRFLP. Can. J. For. Res. 42:1173--77 
66. Long SJ, Williams DW, Hajek AE. 2009. Sirex species (Hymenoptera: Siricidae) and their parasitoids in Pinus sylvestris in eastern North America. Can. Entomol. $141: 153--57$

67. Madden JL. 1968. Behavioural responses of parasites to the symbiotic fungus associated with Sirex noctilio F. Nature 218:189--90

68. Madden JL. 1968. Physiological aspects of host tree favourability for the woodwasp, Sirex noctilio F. Proc. Ecol. Soc. Aust. 3:147--49

69. Madden JL. 1975. Bacteria and yeasts associated with Sirex noctilio. J. Invertebr. Pathol. 25:283--87

70. Madden JL. 1981. Egg and larval development in the woodwasp, Sirex noctilio F. Aust. J. Zool. 29:493--506

71. Madden JL. 1988. Sirex in Australasia. In Dynamics of Forest Insect Populations, ed. AA Berryman, pp. 407--29. New York: Plenum

72. Madden JL, Coutts MP. 1979. The role of fungi in the biology and ecology of woodwasps (Hymenoptera: Siricidae). In Insect-Fungus Symbiosis, ed. LR Batra, pp. 165--74. Montclair, NJ: Allanheld, Osmun \& Co.

73. Martinez AS, Fernandez-Arhex V, Corley JC. 2006. Chemical information from the fungus Amylostereum areolatum and host-foraging behaviour in the parasitoid Ibalia leucospoides. Physiol. Entomol. 31:336--40

73a. Martinez AS, Villacide J, Ajo AAF, Martinson SJ, Corley JC. 2014. Sirex noctilio flight behavior: toward improving current monitoring techniques. Entomol. Exp. Appl. 152:135--40

74. Morgan FD. 1968. Bionomics of Siricidae. Annu. Rev. Entomol. 13:239--56

75. Morris EE, Hajek AE. 2014. Eat or be eaten: fungus and nematode switch off as predator and prey. Fungal Ecol. 11:114--21

76. Morris EE, Jimenez A, Long SJ, Williams DW, Hajek AE. 2012. Variability in growth of Deladenus siricidicola on strains of the white rot fungus Amylostereum areolatum. Biocontrol 57:677--86

77. Morris EE, Kepler RM, Long SJ, Williams DW, Hajek AE. 2013. Phylogenetic analysis of Deladenus nematodes parasitizing northeastern North American Sirex species. J. Invertebr. Pathol. 113:177--83

78. Mlonyeni XO, Wingfield BD, Wingfield MJ, Ahumada R, Klasmer P, et al. 2011. Extreme homozygosity in Southern Hemisphere populations of 
Deladenus siricidicola, a biological control agent of Sirex noctilio. Biol. Control 59:348--53

79. Neumann FG, Morey JL, McKimm RJ. 1987. The Sirex wasp in Victoria. Dep. Conserv. For. Lands Bull. 29. 41 pp.

80. Nielsen C, Williams DW, Hajek AE. 2009. Putative source of the invasive Sirex noctilio fungal symbiont, Amylostereum areolatum, in the eastern United States and its association with native siricid woodwasps. Mycol. Res. 113:1242--53

81. Olatinwo R, Allison J, Meeker J, Johnson W, Streett D, et al. 2013. Detection and identification of Amylostereum areolatum (Russulales: Amylostereaceae) in the mycangia of Sirex nigricornis (Hymenoptera: Siricidae) in central Louisiana. Environ. Entomol. 42:1246--56

82. Pazoutova S, Srutka P, Holusa J, Chudickova M, Kolarik M. 2010. Diversity of xylariaceous symbionts in Xiphydria woodwasps: role of vector and a host tree. Fungal Ecol. 3:392--401

83. Pietrantuono A, Fernandez-Arhex V, Jofre N, Corley J. 2012. Food and host searching decisions made by Ibalia leucospoides (Hymenoptera: Ibaliidae), a parasitoid of Sirex noctilio (Hymenoptera: Siricidae). J. Insect Behav. 25:320--27

84. Rius M, Darling JA. 2014. How important is intraspecific genetic admixture to the success of colonising populations? Trends Ecol. Evol. 29:233--42

85. Roderick GK, Hufbauer R, Navajas M. 2012. Evolution and biological control. Evol. Appl. 5:419--23

86. Roderick GK, Navajas M. 2003. Genes in new environments: genetics and evolution in biological control. Nat. Rev. Genet. 4:889--99

87. Roman J, Darling JA. 2007. Paradox lost: genetic diversity and the success of aquatic invasions. Trends Ecol. Evol. 22:454--64

88. Ryan K, de Groot P, Smith SM. 2011. Evidence of interaction between Sirex noctilio and other species inhabiting the bole of Pinus. Agric. For. Entomol. 14:187--95

89. Ryan K, de Groot P, Davis C, Smith S. 2012. Effect of two bark beetle-vectored fungi on the on-host search and oviposition behavior of the introduced woodwasp Sirex noctilio (Hymenoptera: Siricidae) on Pinus sylvestris trees and logs. J. Insect Behav. 25:453--66 
90. Ryan K, de Groot P, Nott RW, Drabble S, Ochoa I, et al. 2012. Natural enemies associated with Sirex noctilio (Hymenoptera: Siricidae) and S. nigricornis in Ontario, Canada. Environ. Entomol. 41:289--97

91. Ryan K, Hurley BP. 2012. Life history and biology of Sirex noctilio. See Ref. 99, pp. $15--30$

92. Ryan K, Moncalvo JM, de Groot P, Smith SM. 2011. Interactions between the fungal symbiont of Sirex noctilio (Hymenoptera: Siricidae) and two bark beetlevectored fungi. Can. Entomol. 143:224--35

93. Santini A, Ghelardini L, De Pace C, Desprez-Loustau ML, Capretti P, et al. 2013. Biogeographical patterns and determinants of invasion by forest pathogens in Europe. New Phytol. 197:238--50

94. Sarvary MA, Cooperband MF, Hajek AE. 2014. The importance of olfactory and visual cues in developing better monitoring tools for Sirex noctilio (Hymenoptera: Siricidae). Agric. For. Entomol. Epub ahead of print; doi: 10.1111/afe.12077

95. Simpson RF. 1976. Bioassay of pine oil components as attractants for Sirex noctilio (Hymenoptera: Siricidae) using electroantennogram techniques. Entomol. Exp. Appl. 19:11--18

96. Simpson RF, McQuilkon RM. 1976. Identification of volatiles from felled Pinus radiata and the electroantennograms they elicit in Sirex noctilio. Entomol. Exp. Appl. 19:205--13

97. Six DL, Poulsen M, Hansen AK, Wingfield MJ, Roux J, et al. 2011. Anthropogenic effects on interaction outcomes: examples from insect-microbial symbioses in forest and savanna ecosystems. Symbiosis 53:101--21

98. Slippers B, Coutinho TA, Wingfield BD, Wingfield MJ. 2003. The genus Amylostereum and its association with woodwasps: a contemporary review. S. Afr. J. Sci. 99:70--74

99. Slippers B, de Groot P, Wingfield MJ, eds. 2012. The Sirex Woodwasp and Its Fungal Symbiont: Research and Management of a Worldwide Invasive Pest. Dordrecht: Springer Sci. Bus. Media. 301 pp.

100. Slippers B, Hurley BP, Mlonyeni OX, de Groot P, Wingfield MJ. 2012. Factors affecting the efficacy of Deladenus siricidicola in biological control systems. See Ref. 99, pp. 135--48 
101. Slippers B, Wingfield BD, Coutinho TA, Wingfield MJ. 2002. DNA sequence and RFLP data reflect geographical spread and relationships of Amylostereum areolatum and its insect vectors. Mol. Ecol. 11:1845--54

102. Slippers B, Wingfield MJ. 2012. Sirex research and management: future prospects. See Ref. 99, pp. 287--95

103. Slippers B, Wingfield MJ, Coutinho TA, Wingfield BD. 2001. Population structure and possible origin of Amylostereum areolatum in South Africa. Plant Pathol. 50:206--10

104. Spradbery JP. 1970. The biology of Ibalia drewseni Borries (Hymenoptera: Ibaliidae), a parasite of siricid woodwasps. Proc. R. Entomol. Soc. A 45:104--13

105. Spradbery JP. 1974. The responses of Ibalia species (Hymenoptera: Ibaliidae) to the fungal symbionts of siricid woodwasp hosts. J. Entomol. Ser. A 48:217--22

106. Spradbery JP, Kirk AA. 1978. Aspects of the ecology of siricid woodwasps (Hymenoptera: Siricidae) in Europe, North Africa and Turkey with special reference to the biological control of Sirex noctilio F. in Australia. Bull. Entomol. Res. 68:341--59

107. Tabata M, Harrington TC, Chen W, Abe Y. 2000. Molecular phylogeny of species in the genera Amylostereum and Echinodontium. Mycoscience 41:585--93

108. Talbot PHB. 1977. The Sirex-Amylostereum-Pinus association. Annu. Rev. Phytopathol. 15:41--54

109. Takasuka TE, Brook AJ, Lewin GR, Currie CR, Fox BG. 2013. Aerobic deconstruction of cellulosic biomass by an insect-associated Streptomyces. Sci. Rep. 3:1030

110. Thomsen IM, Koch J. 1999. Somatic compatibility in Amylostereum areolatum and $A$. chailletii as a consequence of symbiosis with siricid woodwasps. Mycol. Res. 103:817--23

111. Thompson BM. 2013. Community ecology and Sirex noctilio: interactions with microbial symbionts and native insects. $\mathrm{PhD}$ thesis. Univ. Maryland, College Park

112. Thompson BM, Grebenok RJ, Behmer ST, Gruner DS. 2013. Microbial symbionts shape the sterol profile of the xylem-feeding woodwasp, Sirex noctilio. J. Chem. Ecol. 38:129--39

113. Thompson BM, Bodart J, Ewen CMC, Gruner DS. 2014. Adaptations for symbiont-mediated external digestion in Sirex noctilio (Hymenoptera: Siricidae). Ann. Entomol. Soc. Am. 107:453--60 
114. Van der Nest MA, Steenkamp ET, Wilken MP, Stenlid J, Wingfield MJ, et al. 2013. Mutualism and asexual reproduction influence recognition genes in a fungal symbiont. Fungal Biol. 117:439--50

115. Van der Nest MA, Wingfield BD, Wingfield MJ, Stenlid J, Vasaitis R, Slippers B. 2012. Genetics of Amylostereum species associated with Siricidae woodwasps. See Ref. 99, pp. 81--94

116. Vasiliauskas R, Stenlid J, Thomsen IM. 1998. Clonality and genetic variation in Amylostereum areolatum and A. chailletii from Northern Europe. New Phytol. 139:751--58

117. Villacide JM, Corley JC. 2012. Ecology of the woodwasp Sirex noctilio: tackling the challenge of successful pest management. Int. J. Pest Manag. 58:249--56

118. Wermelinger B, Rigling A, Mathis DS, Dobbertin M. 2008. Assessing the role of bark- and wood-boring insects in the decline of Scots pine (Pinus sylvestris) in the Swiss Rhone Valley. Ecol. Entomol. 33:239--49

119. Williams DW, Zylstra KE, Mastro V. 2012. Ecological considerations in using Deladenus (=Beddingia) siricidicola for the biological control of Sirex noctilio in North America. See Ref. 99, pp. 135--48

120. Wooding AL, Wingfield MJ, Hurley BP, Garnas JR, de Groot P, Slippers B. 2013. Lack of fidelity revealed in an insect-fungal mutualism after invasion. Biol. Lett. 9:20130342

120a. Yek SH, Slippers B. 2014. Biocontrol opportunities to study microevolution in invasive populations. Trends Ecol. Evol. 29:429--30

121. Yemshanov D, Koch FH, Ben-Haim Y, Smith WD. 2010. Detection capacity, information gaps and the design of surveillance programs for invasive forest pests. J. Environ. Manag. 91:2535--46

122. Yemshanov D, Koch FH, McKenney DW, Downing MC, Sapio F. 2009. Mapping invasive species risks with stochastic models: a cross-border United States-Canada application for Sirex noctilio fabricius. Risk Anal. 29:868--84

123. Yemshanov D, McKenney DW, Pedlar JH, Koch FH, Cook D. 2009. Towards an integrated approach to modeling the risks and impacts of invasive forest species. Environ. Rev. 17:163--78 
124. Yousuf F, Gurr GM, Carnegie AJ, Bedding RA, Bashford R, et al. 2014. The bark beetle, Ips grandicollis, disrupts biological control of the woodwasp, Sirex noctilio, via fungal symbiont interactions. FEMS Microbiol. Ecol. 88:38-47

125. Yu Q, de Groot P, Leal I, Davis C, Ye W, Foord B. 2009. Characterization of Deladenus siricidicola (Tylenchida: Neotylenchidae) associated with Sirex noctilio (Hymenoptera: Siricidae) in Canada. Int. J. Nematol. 19:23--32

126. Zondag R. 1962. A nematode disease of Sirex noctilio. N.Z. For. Ser. Interim Res. Release. 6 pp.

127. Zylstra KE, Dodds KJ, Francese JA, Mastro V. 2010. Sirex noctilio in North America: the effect of stem-injection timing on the attractiveness and suitability of trap trees. Agric. Forest Entomol. 12:243--50

128. Zylstra KE, Mastro VC. 2012. Common mortality factors of woodwasp larvae in three northeastern United States host species. J. Insect Sci. 12:1--8

\section{RELATED RESOURCES}

Comprehensive list of Sirex-related literature:

http://fabinet.up.ac.za/index.php/sirex-literature

Sirex listserver connecting the global community working on this pest complex:

sirex@kendy.up.ac.za

Sirex working group website: http://www.woodwasps.com/ 


\section{A MODEL TO STUDY MICROEVOLUTION OF INVASIVE PESTS AND BIOLOGICAL CONTROL}

Rius \& Darling (84) highlighted the need for systems to experimentally test hypotheses regarding the role of microevolutionary processes in invasive populations. $S$. noctilio and $A$. areolatum, especially the options for biologically controlling this pest, provide excellent opportunities for developing an experimental system (120a). Such a system would offer depth of background knowledge, numerous collections spanning vast areas and decades of collection, an active global community working on the system, extensive laboratory protocols, as well as molecular and other tools to manipulate and study all the organisms involved. It would also offer the opportunity to manipulate experimental and control populations in the laboratory or the field to address questions such as the influence of genetic diversity and phenotypic plasticity on adaptability and the evolution of virulence or resistance. In terms of evolution of symbioses, the Sirex system also provides opportunities to study fidelity and specificity in host-mutualist and host-parasite interactions. The consequences of long-term asexual transmission (e.g., 22) of basidiomycete symbionts and aspects of the evolution of sexual reproduction and ploidy in fungi can also be studied in this system. Such studies will be enhanced by the expected release of the genomes of the wasp, fungus, and parasitic nematode.

\section{KEY TERMS AND DEFINITIONS}

Admixture: interbreeding between previously isolates populations

Allee effects: effects that reduce individual fitness at low population densities

Arthrospores or oidia: small mycelial fragments that detach from the mycelial body

Cospeciation: parallel speciation in the symbiont and host, evident in congruent molecular phylogenies

Fidelity: a process wherein a genetically identical symbiont is transmitted directly or vertically between generations of the host

Haplodiploid: most hymenopterans produce haploid males from unfertilized eggs and diploid females from fertilized eggs

Horizontal transmission of symbionts: genotypes of the symbiont are exchanged between unrelated individuals or species of the host 
Mycangia: two specialized, internal sac-like structures at the base of the ovipositor in Sirex females that contain propagules of an Amylostereum species

Mycetophagy: deriving the majority of nutrition from feeding on fungi

Pheromone: chemicals produced by individual organisms that affect the behavior of other members of its species

Resistance (in wasps): in the Sirex system, includes the ability to resist initial infection or the infection of eggs

Sirex system: refers to the wasp and its symbionts and natural enemies

Sopron and Kamona strains: refers to the locations in Hungary and Tasmania where strains of the parasitic nematode $D$. siricidicola were isolated

Vegetative compatibility groups: mycelium of two isolates of a fungus will fuse in culture when the alleles at incompatibile loci are identical

Vertical transmission: direct sharing of a symbiont between generations of the wasp

Virulence: in the Sirex system, reflects reduced or an absence of sterilization of eggs 
Supplemental Table 1. The stages of population development of S. noctilio, based on Villacide \& Corley (2012), and incorporating hypotheses regarding the influence of the different stages on the evolution of virulence in nematode populations and dispersal pressure on female wasps.

\begin{tabular}{|c|c|c|c|c|c|c|}
\hline $\begin{array}{l}\text { Sirex } \\
\text { population }\end{array}$ & $\begin{array}{l}\text { Plantation } \\
\text { infestation } \\
\text { level }\end{array}$ & $\begin{array}{l}\text { Sirex spatial } \\
\text { dynamics }\end{array}$ & Trees attacked & $\begin{array}{l}\text { Transmission cost } \\
\text { for sterilizing } \\
\text { eggs }{ }^{1}\end{array}$ & $\begin{array}{l}\text { Evolution of } \\
\text { reduced } \\
\text { virulence }^{1,2}\end{array}$ & $\begin{array}{l}\text { Dispersal } \\
\text { pressure/potential }^{1}\end{array}$ \\
\hline Endemic & $\begin{array}{l}<1 \% \text { tree } \\
\text { mortality }\end{array}$ & $\begin{array}{l}\text { No spatial } \\
\text { aggregation }\end{array}$ & Stressed trees & +++ & +++ & + \\
\hline $\begin{array}{l}\text { Pre- } \\
\text { outbreak }\end{array}$ & $\begin{array}{l}1-5 \% \text { tree } \\
\text { mortality }\end{array}$ & $\begin{array}{l}\text { Increasing spatial } \\
\text { aggregation }\end{array}$ & $\begin{array}{l}\text { Stressed and } \\
\text { some vigorous } \\
\text { trees }\end{array}$ & ++ & ++ & ++ \\
\hline Outbreak & $\begin{array}{l}>5 \% \text { tree } \\
\text { mortality }\end{array}$ & $\begin{array}{l}\text { Expanding } \\
\text { spatially local foci } \\
\text { to cover large } \\
\text { areas }\end{array}$ & $\begin{array}{l}\text { Stressed and } \\
\text { vigorous trees }\end{array}$ & + & + & +++ \\
\hline
\end{tabular}

\footnotetext{
${ }^{1}$ With reference to selection in $D$. siricidicola populations; virulence defined as percentage of S. noctilio eggs infected

${ }^{2}+=$ low $++=$ medium; +++ = high
} 


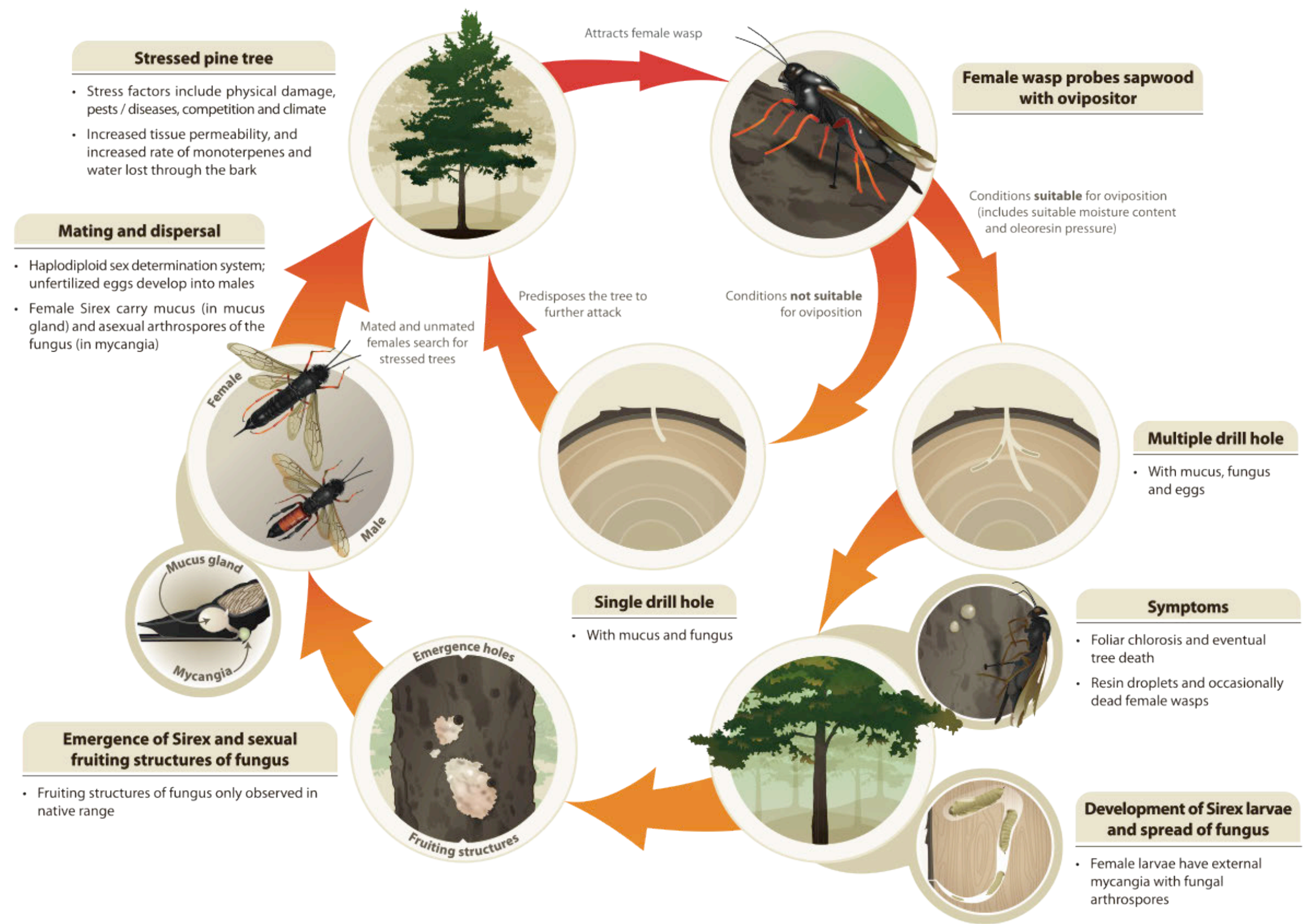

Supplementaưg

Reproduced with permission from Ryan \& Hurley (91) (Springer). 


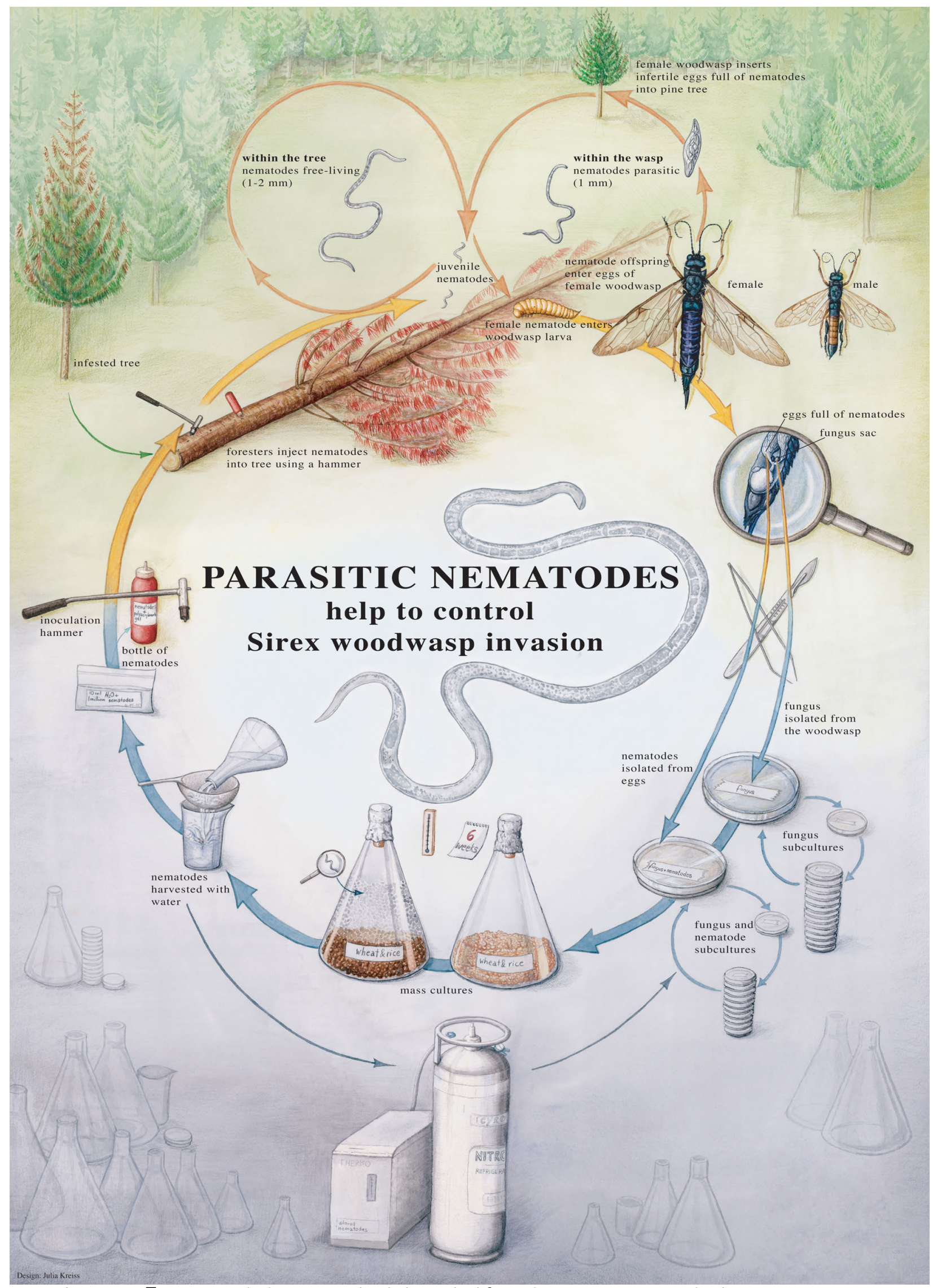

SupplementaưEgure 2. Deladenus siricidicola bi-cyclic life cycle, mass rearing and release strategy. Reproduced with permission from Slippers et al. (1008)(Springer). 